\title{
FACTORS DETERMINING BANK LOAN APPROVAL AS SOURCE OF FINANCING FOR MICRO, SMALL, AND MEDIUM ENTERPRISES (MSME) IN JAKARTA
}

\author{
Margarita Ekadjaja ${ }^{1}$, Halim Putera Siswanto ${ }^{2}$, Agus Zainul Arifin ${ }^{3}$ \\ ${ }^{1}$ Management Department - Tarumanagara University, Jakarta \\ Email : rita_e11510@yahoo.com \\ ${ }^{2}$ Management Department - Tarumanagara University, Jakarta \\ Email : halimputera@yahoo.com \\ ${ }^{3}$ Management Department - Tarumanagara University, Jakarta \\ Email : agusza1808@gmail.com
}

\begin{abstract}
In running business, the owners of Micro, Small, and Medium Enterprises (MSME) have main weaknesses, in which they do not conduct good accounting system or financial records, thus creating difficulties in developing analysis for future business planning. Most of MSME owners run their business by relying on instincts, while business analysis and accounting system are necessary when they apply for bank loan.
\end{abstract}

The aim of this study is to reveal some variables of MSME that become the determinants of their bank loans approval. These variables are: Business Age since Establishment, Total Assets Turnover, Owner's Total Assets, Credit Duration, Owner's Education Level, Good Relationship with the Bank, Collateral Amount, and Loan Repayment Criteria. The samples of this study were taken from entrepreneurs selling clothes and apparels in Tanah Abang by conducting direct interview and fulfilling the questionnaire. The questionnaire consists of three major parts, which are business owner's profile, credit analysis, and evaluation on simple financial report. This study uses logistic regression method, in which there is only one dependant variable with dummy 1-0 (Bank Loan Approval, granted $=1$ and rejected $=0$ ) along with eight independent variables.

This study concludes that Business Age since Establishment, Total Assets Turnover, Owner's Education Level, Collateral Amount, and Loan Repayment Criteria, have positive and significant effects on Bank Loan Approval. Meanwhile, Owner's Total Assets, Credit Duration, and Good Relationship with the Bank do not affect Bank Loan Approval significantly.

Keywords: MSME, bank loan approval, logistic regression

\section{Introduction}

Indonesia is a developing country that keeps increasing and improving its national economic, in order to achieve the greater economic growth. National economic growth is heavily determined by local economic development, while local economic is commonly supported by small and medium-scale economic activities. Business units included in the category of Micro, Small, and Medium Enterprises (MSME) become the main part of local and national economic activities.

Wismiarsi et. al (2008: 18) states that most of business like MSME have not been developed optimally due to their inability to access the sources of financing, which can inhibit their development and growth, especially in the way to acquire credit support, loan requirement, and even the credit procedures which are too burdensome. Therefore, MSME owners are still difficult to apply for bank loan.

Banks' role in financing MSME can support their productive activities. The fund in form of credit or bank loan must be utilized as well as possible to increase the productivity of MSME. In contrast, there are still many MSME owners who find difficult to apply for bank loan. Bank's officers have addressed some reasons that those entrepreneurs are lack of knowledge on accounting system or financial records, especially those related to business capital, operational-related matters, selling price for resellers, as well as profit expectation. Thus, not all loan applications can be granted by the Bank. 
This study aims to reveal the effects of company age, asset turnover, total assets, loan duration, owner's level of education, good relationship with the Bank, collateral amount, and loan approval criteria, on the amount of loan approved by the Bank, either partially or simultaneously.

\section{Definition of MSME}

Based on Constitution of the Republic of Indonesia Number 9 Year 1995 on Small Business followed by the Government Regulation Number 44 Year 1997 on Partnership, as well as the Constitution of the Republic of Indonesia Number 20 Year 2008, the definition of MSME are as follows: (a) "Micro Business is an economically productive business owned by individuals and/or institutions that fulfil the criteria of Micro Business as determined by the Constitution on MSME, which are: possessing Net Asset Rp 50 millions at the most (excluding land and building), or generating annual revenue Rp 300 millions at the most". (b) "Small Business an economically productive business, which is independent, managed by individuals or institutions, that neither a subsidiary nor a branch of a company owned or possessed, either directly or indirectly as part of medium or large-scale business, that fulfill the criteria of Small Business as determined by the Constitution on MSME, which are: possessing Net Asset more than Rp 50 millions until Rp 500 millions (excluding land and building), or generating annual revenue more than $\mathrm{Rp} 300$ millions until $\mathrm{Rp}$ 2.5 billions at the most". (c) "Medium Business an economically productive business, which is independent, managed by individuals or institutions, that neither a subsidiary nor a branch of a company owned, either directly or indirectly as part of small or large-scale business with net assets or annual revenue as determined by the Constitution on MSME, which are: possessing Net Asset more than Rp 500 millions until Rp 10 billions (excluding land and building), or generating annual revenue more than $\mathrm{Rp} 2.5$ billions until $\mathrm{Rp} 50$ billions at the most".

According to Kuncoro (2007), there are three habits that have been entrusted and possessed by most MSME in Indonesia, which are: (a) No job division and obvious delegation between administration and operationalrelated matters. Most of small business is managed without obvious system. This could happen due to the management that also plays the role as the owner. Consequently, business management often utilizes their relatives or other family members ignoring the human resource competencies. (b) Low access to loanproviding institutions, such as bank. Thus, this MSME is already assumed unbankable. They tend to rely business financing on their own equity or other non-bank sources, such as family members, relatives, merchants, intermediaries, or even illegal bankers. (c) Most of these business owners have not acquired legal status due to the difficulty to get the acknowledgement from the association. They have not realized that participating in the association can provide a lot of benefits to them. This phenomenon will affect the productivity and performance of MSME.

\section{The Role of MSME}

MSME has a main and important role, which is providing job opportunities for community. MSME also has complementary role with big enterprises in creating job opportunities as well as supporting the economic growth (Giaoutzi, et al: 2016). MSME can reduce income disparity especially in developing countries. The existence of MSME in Indonesia also has a classical role, which is decreasing unemployment and balancing revenue (Tambunan, 2002). Hubeis (2009: 2) states that MSME has a strength point, which can be the fundamental of entrepreneurship because this kind of simple organization can enhance the manpower-based economic having orientation to exported and substitute imported products (forex-generating business).

MSME is viewed as a kind of business that has scale limitation, which cannot compete with big enterprises that have much strength, of which one of them is the capability to reach economies of scale in their production activities. In order to overcome the problem, most MSME have their own strategies by creating unique and special products (Wibowo et al, 2002). On the other hand, the limited business-scope of MSME causes the limitation in their marketing activities in order to comprehend the characteristics of consumers. The communication process with consumers can occur in a quick way and often create more intimate 
interpersonal relationship. This phenomenon makes MSME become more adaptive and flexible compared to that experienced by big enterprises.

Some advantages of MSME compared to other big enterprises are (Partomo and Rachman, 2002): (1) Most MSME have interrelationship among the workers and the owners (2) MSME can apply higher innovation in developing products (3) MSME are flexible and able to adapt to dynamic market condition compared to those of big enterprises which is usually beureaucratic (4) MSME have managerial movement and the role of entrepreneurship.

\section{Problems Faced by MSME}

Urata (2000 in Hapsari, 2014) stated that MSME commonly has many financial and non-financial problems. Financial problems are the mismatch between available funds and those that can be accessed by MSME, no systematic approach in financing, high transaction costs due to complicated credit procedure, the lack of access to formal source of financing, high interest charged, and the lack of managerial and financial competences. Meanwhile, non-financial problems are the lack of knowledge in production technology, marketing, human resource, finance, and accounting.

Although there are many credit offers from banks as well as various supports from state-owned enterprises, the source from personal equity still dominates the financing for MSME activities. This is because the bank locations are too far from owners who live in rural areas, the credit requirements are too difficult to be fulfilled, the administrative matters are too complicated, and the information on credit offers as well as the procedures is too limited.

\section{Loan for MSME}

Limited capital is a weakness experienced by most MSME stakeholders. Loan for MSME is a loan for debitors of productive business which fulfil the criteria to certain extents, which are mainly net worth and annual sales. The Regulation of Bank of Indonesia number 14/22/PBI/2012 about loan distribution or financing by banks and technical supports in developing MSME's business, states that the banks in Indonesa have to distribute at least $20 \%$ of total loan portfolio to MSME. The success of MSME in Indonesia is related to the role and support from government in encouraging credit distribution to MSME.

Various loans or financing schemes from government are connected to the duty and economic development program in certain business sectors, such as food security, farm, and plantation. Government's role in MSME's credit scheme stands on the side of fund availability (state budget) to subsidice the interest of particular credit scheme, while the fund for financing wholefully comes from the banks appointed by government to execute this program. Besides, government has a role in preparing MSME to be financed by such scheme, stipulating policy and priorities on business that are eligible to acquire the loan, conduct coaching and accompaniment during credit period, and facilitating the relationship among MSME and other parties.

Currently, the credit scheme which is very familiar in community is Kredit Usaha Rakyat (KUR), which is especially distributed to MSME listed in the feasible category, but do not have sufficient collateral to meet the bank's requirements. $K U R$ is a loan or financing for MSME and cooperative that are not acquiring other financing from banks or government, when the credit is being applied. The final goal of $K U R$ program is to enhance economic activities, eliminate poverty, and absorb manpower (Bank of Indonesia).

\section{Research Method}

The subject of this study is the MSME operating business outlets in Tanah Abang market, located in Central Jakarta, while the object of this study is Business Age since Establishment (BASE), Total Assets Turnover (TATO), Owner's Total Assets (OTA), Credit Duration (CD), Owner's Education Level (OEL), Good 
Relationship with the Bank (GRB), Collateral Amount (CA), and Loan Repayment Criteria (LRC). In this study, Tanah Abang market is chosen due to its existence as the main and largest textile trading activities in Jakarta, but in contrast there are not many studies yet conducted on MSME in this location. Data comes in form of primary data collected from interview and questionnaire distributed to MSME owners in secondhalf of 2016. The questionnaire is in form of open questions on business owner's profile, credit analysis, and evaluation on business and financial condition, which totals 32 numbers overally. This study has a characteristic of descriptive and verificative. In this study, the population is MSME owners in Tanah Abang market in Central Jakarta, the samples are MSME selling clothes and apparels located in Block A, B, and F (as many as 120 units) by using non-probability sampling techniques, and then followed by data analysis using the logistic regression method.

\section{Result and Discussion}

\section{Data Analysis \\ Multicollinearity Test}

This test aims to find out whether the correlation among independent variables exists in this regression model. Decision criteria (Ghozali, 2011): Correlation less than 0.9, means that there is no multicollinearity in the model.

Table 1. The Result of Multicollinearity Test Correlation Matrix

\begin{tabular}{|c|c|c|c|c|c|c|c|c|c|}
\hline Description & Constant & BASE & TATO & OTA & $C D$ & OEL & GRB & $\mathrm{CA}$ & LRC \\
\hline $\begin{array}{ll} & \text { Constant } \\
& \text { BASE } \\
& \text { TATO } \\
\text { SAtep } 1 & \text { OTA } \\
& \text { CD } \\
& \text { OEL } \\
& \text { GRB } \\
& \text { CA } \\
& \text { LRC }\end{array}$ & 1.000 & $\begin{array}{r}.317 \\
1.000\end{array}$ & $\begin{array}{l}.869 \\
-.336 \\
1.000\end{array}$ & $\begin{array}{r}-.787 \\
-.628 \\
.558 \\
1.000\end{array}$ & $\begin{array}{r}.138 \\
.219 \\
-.211 \\
-.249 \\
1.000\end{array}$ & $\begin{array}{r}-.224 \\
-.079 \\
.215 \\
.126 \\
-.374 \\
1.000\end{array}$ & $\begin{array}{r}-.210 \\
-.243 \\
.080 \\
.171 \\
-.205 \\
-.144 \\
1.000\end{array}$ & $\begin{array}{r}.061 \\
-.075 \\
.005 \\
.008 \\
.022 \\
-.176 \\
-.043 \\
1.000\end{array}$ & $\begin{array}{r}-.013 \\
-.339 \\
.128 \\
.003 \\
-.328 \\
.031 \\
.183 \\
.003 \\
1.000\end{array}$ \\
\hline
\end{tabular}

Table 1 provides the correlations among independent variables. The highest correlation is only 0.558 (less than 0.9) between Total Assets Turnover (TATO) and Owner's Total Assets (OTA). This means that among these independent variables, there is no strong relationship. In other word, this model does not contain multicollinearity effect.

\section{Test of Goodness of Fit $\left(\mathbf{R}^{2}\right)$}

Test of Goodness of Fit is used to measure the fitness of model being used. The test of logistic regression model fit is conducted by using Hosmer and Lemeshow's Goodness of Fit Test.

Block 0: Beginning Block

Table 2. Iteration History ${ }^{a, b, c}$

\begin{tabular}{|c|c|c|c|}
\hline \multirow{2}{*}{\multicolumn{2}{|c|}{ Iteration }} & \multirow[t]{2}{*}{-2 Log likelihood } & Coefficients \\
\hline & & & Constant \\
\hline \multirow{3}{*}{ Step 0} & 1 & 205.270 & .267 \\
\hline & 2 & 205.270 & .268 \\
\hline & 3 & 205.270 & .268 \\
\hline
\end{tabular}

Block 1: Method = Enter 
Table 3. Model Summary

\begin{tabular}{|c|r|r|r|}
\hline Step & -2 Log likelihood & Cox \& Snell R Square & Nagelkerke R Square \\
\hline 1 & $91.691^{\mathrm{a}}$ & .531 & .712 \\
\hline
\end{tabular}

a. Estimation terminated at iteration number 7 because parameter estimates

changed by less than .001

Table 2 and 3 shows the comparison between -2LL (-2 Log likelihood) Block 0 and -2LL Blok 1. It can be seen that the value of -2LL in Block 0 is 205.270 and the value of -2LL in Block 1 is 91.691. Based on the result, it can be concluded that the hypothesized model fit the data, because there is a decrease of value from Block 0 to Block 1, with the range as much as 113.579. The SPSS program also displays the ranges as follows:

Table 4. Omnibus Test of Model Coefficients

\begin{tabular}{|c|c|c|c|c|}
\hline \multicolumn{2}{|c|}{} & Chi-square & Df & Sig. \\
\hline \multirow{3}{*}{ Step 1 } & Step & 113.579 & 8 & .000 \\
\cline { 2 - 5 } & Block & 113.579 & 8 & .000 \\
\cline { 2 - 5 } & Model & 113.579 & 8 & .000 \\
\hline
\end{tabular}

In Table 4, it can be seen that the range is 113.579 with significance value $=0.000$ (less than 0.05 ) proving that the addition of independent variable provides significant impact to the model. In other word, the model is fit. Moreover, Hosmer and Lemeshow's Goodness of Fit Test provide the result that there is no difference between the hypothesized model and data. Therefore, this model is fit.

Table 5. The Result of Hosmer and Lemeshow's Goodness of Fit Test

\begin{tabular}{|c|c|c|c|}
\hline Step & Chi-square & Df & Sig. \\
\hline 1 & 7.785 & 8 & .455 \\
\hline
\end{tabular}

From Table 5, the Chi-square value is 7.785 with significance value $=0.455$ and degree of freedom $(\mathrm{df})=8$. It can be seen that the sig. value is greater than $\alpha(0.05)$, which means that the decision is do not reject $\mathrm{H}_{0}$. Thus, there is no significant difference between the model and the observed value. So, the model is considered capable in predicting the observed value, or it can be said that this model can be accepted due to the fitness to its observed data.

\section{G Test}

This test shows that overally the logistic model can explain the effects of independent variables on the dependant one. In Table 4, the sig. values are less than 0.05. So, it can be concluded that all independent variables affect the access to bank loan approval.

\section{Coefficient of Determination Test (Nagelkerke R-Square)}

Nagelkerke (1991) states that the coefficient of determination has to describe the proportion of variation explained by the model. The value has to range between 0 and 1, with 0 showing that the model does not explain the variation, and 1 showing that the model perfectly explains the variation. Table 3 shows that the Nagelkerke R-Square is 0.712 , which means that this model has predictive power as much as $71.2 \%$ that can be explained by the independent variables, while the remaining $28.8 \%$ of variation is explained by other factors not included in the model.

Table Classification Analysis

Tabel 6. Classification Table ${ }^{a}$

\begin{tabular}{|c|c|c|c|c|c|}
\hline & \multirow{3}{*}{\multicolumn{2}{|c|}{ Observed }} & \multicolumn{3}{|c|}{ Predicted } \\
\hline & & & \multicolumn{2}{|c|}{ Access to Bank Loan } & \multirow{2}{*}{$\begin{array}{c}\text { Percentage of } \\
\text { Correctness }\end{array}$} \\
\hline & & & Rejected & Granted & \\
\hline \multirow{3}{*}{ Step 1} & \multirow{2}{*}{ Access to Bank Loan } & \multirow{2}{*}{$\begin{array}{l}\text { Rejected } \\
\text { Granted }\end{array}$} & 38 & 7 & 84.4 \\
\hline & & & 9 & 66 & 88.0 \\
\hline & \multicolumn{2}{|c|}{ Overall Percentage } & & & 86.2 \\
\hline
\end{tabular}

The cut value is .500 
From Table 6, it can be known that there are 45 respondents whose credit applications get rejected by the banks, while the observation result generates 38 respondents who get rejected. Thus, the level of accuracy of this model is $84.4 \%(=38 / 45)$. The amount of samples whose credit applications get granted is 75 respondents, while the observation result generates 66 respondents who get granted. Thus, the level of accuracy of this model is $88 \%(=66 / 75)$ or in other word, the overall accuracy of this model is $86.2 \%$.

\section{Wald Test}

This test is conducted in order to find out whether each of the independent variables has positive effect on the dependant variable, which is Bank Loan Approval.

The criteria of decision making (Ghozali, 2011): (a) If the value of Wald $<$ Chi Square table, thus $\mathrm{H}_{0}$ is accepted or Significance Value $>0.05$, thus $\mathrm{H}_{0}$ is accepted. This means that there is no effect of the independent variables on the dependant variable. (b) If the value of Wald $>$ Chi Square table, thus $\mathrm{H}_{0}$ is rejected or Significance Value $<0.05$, thus $\mathrm{H}_{0}$ is rejected. This means that there is significant effect of the independent variables on the dependant variable.

Table 7. Variables in the Equation

\begin{tabular}{|c|c|c|c|c|c|c|}
\hline & Description & B & S.E. & Wald & $\mathrm{df}$ & Sig. \\
\hline \multirow{9}{*}{ Step $1^{\mathrm{a}}$} & BASE & .851 & .426 & 3.981 & 1 & .046 \\
\hline & TATO & 9.495 & 4.240 & 5.014 & 1 & .025 \\
\hline & OTA & -.001 & .006 & .036 & 1 & .851 \\
\hline & CD & -.001 & .040 & .001 & 1 & .971 \\
\hline & OEL & .946 & .455 & 4.319 & 1 & .038 \\
\hline & GRB & -.195 & .278 & .490 & 1 & .484 \\
\hline & CA & 1.113 & .550 & 4.093 & 1 & .043 \\
\hline & LRC & 1.848 & .701 & 6.951 & 1 & .008 \\
\hline & Constant & -6.689 & 2.581 & 6.715 & 1 & .010 \\
\hline
\end{tabular}

Variable(s) entered on step 1: BASE, TATO, OTA, CD, OEL, GRB, CA, LRC

From Table 7, it can be concluded that Business Age since Establishment (BASE), Total Assets Turnover (TATO), Owner's Education Level (OEL), Collateral Amount (CA), and Loan Repayment Criteria (LRC), have positive and significant effects on Bank Loan Approval, because those variables' significance value are less than 0.05. Meanwhile, the variables of Owner's Total Assets (OTA), Credit Duration (CD), and Good Relationship with the Bank (GRB) do not affect Bank Loan Approval significantly due to having significance value greater than 0.05 .

\section{Logistic Regression Equation}

The equation of logistic regression in this study can be acquired as follow:

Ln $\frac{P}{1-\mathrm{P}}=-6,689+0,851 \mathrm{BASE}+9.495$ TATO -0.001 OTA -0.001 CD +0.946 OEL -0.195 GRB $+1.113 \mathrm{CA}+1.848 \mathrm{LRC}$

\section{Discussion}

Based on data analysis result, there are five independent variables that have significant effects on the dependant variable at $\alpha=0.05$, while the other three variables do not. This research result shows that there is positive and significant effect of business age on sales growth, which means that the longer the business has been established, the greater the sales growth becomes. The longer the business age means the more experiences acquired in increasing sales revenue and finally the bank loan application can be more easily granted. This study is consistent to the one conducted by Munizu (2010) viewing that the business that has been long established has a lot of experiences to gain profit compared to those that are still young, thus enabling business owners to achieve greater sales growth. Total Assets Turnover (TATO) has positive and significant effect on sales growth. This means that the higher Total Assets Turnover, the greater sales growth that can be achieved. The higher assets turnover shows the higher level of efficiency in managing 
assets. So, this phenomenon finally can increase sales and causes greater sales growth to occur, which is relevant to the result of the study previously conducted by Munizu (2010). Owner's Education Level (OEL) has positive and significant effect on bank loan approval. This result is consistent to the one conducted by Messah and Wangai (2011) analyzing the factors affecting loan application by small businesses in Meru Central District, Kenya. This means that the higher the owner's education level, the higher the possibility to get the approval. Collateral Amount (CA) as part of 5C criteria in credit feasibility assessment also has positive and significant effect on bank loan approval in this study. Bahsan (2007) mentioned that collateral must have high economic value and fulfil jurisdical aspect in order to pay-off the bad debts. Suyatno (2003) also stated the credit collateral as the assets hand-over to bear debt repayment. The use of collateral is to provide the right for the bank to get repayment whenever a debitor breaches the contract. This result is consistent to the study conducted by Oka et. al (2015) in Bali and Afandi (2010) in Salatiga. This result means that the greater the collateral amount provided, the higher the possibility to get bank loan approval. Loan Repayment Criteria (LRC), which is known as credit quality, has positive and significant effect on bank loan approval, in which this result is similar to the one conducted by Oka et. al (2015) in Bali. This phenomenon means that the better the credit quality, the easier the bank loan to be approved.

Table 7 shows that there is no significant effect of Owner's Total Assets (OTA), Credit Duration (CD), and Good Relationship with the Bank (GRB) on Bank Loan Approval. No significant effect of Owner's Total Assets (OTA) on bank loan approval shows that the huge amount of assets owned also does not guarantee the approval. This result is different from the study conducted by Jumhur (2009), which concludes that assets size has positive and significant relationship on the probability of small business to apply for working capital loan in Pontianak, as well as the study conducted by Ruwanti and Affandi (2014) in Salatiga. Meanwhile, the more frequent the debitors apply for bank loans, does not guarantee that their good relationship with the bank can ensure the approval. And the last, no significant effect of credit duration on bank loan approval is commonly caused by the possibility that debitors cannot always repay the installments on-time.

\section{Conclusion and Suggestion}

Based on the hypotheses testing and discussion related to the problems in this study, the conclusions can be developed as follows: (1) The age of MSME's business affects the sales growth of their cloth and apparel products. The older the business age, the more experiences acquired in increasing their sales which consequently increasing the sales growth. (2) MSME's assets turnover affects their sales growth as well. The higher the assets turnover, the higher the efficiency level in managing their assets thus can increase their sales as well as causing the increase in sales growth. (3) The age of MSME's business and assets turnover simultaneously affect the sales growth of MSME's business in cloth and apparel products.

Some suggestions can be provided from this study are: (1) Government is expected to provide more loan distribution to MSME owners in order to provide external financing facilities in effective and efficient way. By this way, the owners of MSME can develop their business which finally can increase their sales growth, so the increase of national economic activities will become the final result. (2) MSME owners hopefully can use this research result as a motivation to develop their existing business, or even those which is still in planning process, to create new innovations by maximizing the financing facilities from government to increase their sales.

\section{Acknowledgement}

We would like to thank the Directorate of Research and Engagement to Community - Tarumanagara University, which has funded this research. We would also thank the students of the Faculty of Economics - Tarumanagara University, who have contributed in processing this research data. 


\section{References}

Afandi, Pandi. (2010). Analisis Implementasi 5C Bank BPR dalam Menentukan Kelayakan Pemberian Kredit pada Nasabah (Studi Kasus Pada BPR Bank Salatiga dan PT. BPR Kridaharta Salatiga). Jurnal Ilmiah Among Makarti, Vol. 3 (5), pp: 55-69.

Bahsan, M. (2007). Hukum Jaminan dan Jaminan Kredit Perbankan Indonesia. PT. Raja Grafindo Persada, Jakarta.

Ghozali, Imam. (2011). Aplikasi Analisis Multivariate dengan Program IBM SPSS 19, Edisi Kelima. Universitas Diponegoro, Semarang.

Giaoutzi, Maria, Peter Nijkamp, and David Storey. (2016). Small and Medium Size Enterprises and Regional Development. Routledge Library Editions, Oxford.

Hapsari, Ira Maya. (2014) Identifikasi Berbagai Permasalahan yang Dihadapi oleh UKM dan Peninjauan Kembali Regulasi UKM sebagai Langkah Awal Revitalisasi UKM. Jurnal Permana, Vol. 5 (2), pp. 43-47.

Hubeis, Musa. (2009). Menuju Industri Kecil Profesional di Era Globalisasi Melalui Pemberdayaan Manajemen Industri. IPB, Bogor.

Kuncoro, Mudrajad. (2007). Ekonomika Industri Indonesia: Menuju Negara Industri Baru 2030? Andi, Yogyakarta.

Jumhur. (2009). Analisis Permintaan Kredit Modal Kerja Usaha Kecil di Kota Pontianak. Jurnal Bisnis dan Ekonomi (JBE), Vol. 16 (2), pp: 85-96.

Messah, O. B. and Wangai, P. N. (2011). Factors That Influence the Demand for Credit for Credit among Small-Scale Investors: A Case Study of Meru Central District, Kenya. Research Journal of Finance and Accounting, Vol. 2 (2), pp: 74-101.

Munizu, Musran. (2010). Pengaruh Faktor-Faktor Eksternal dan Internal terhadap Kinerja Usaha Mikro dan Kecil (UMK) di Sulawesi Selatan. Jurnal Manajemen dan Kewirausahaan Fakultas Ekonomi Universitas Hasanudin, Vol. 12 (1), pp. 33-41.

Nagelkerke, N.J.D. (1991) A Note on a General Definition of the Coefficient of Determination. Biometrika, Vol. 78 (3), pp. 691-692.

Oka, Komang Wulan Lestari, Gusti Ayu Purnamawati, and Ni Kadek Sinarwati. (2015) Pengaruh Dana Pihak Ketiga, Penilaian 5C Kredit, dan Kualitas Kredit terhadap Keputusan Pemberian Kredit di PT. Bank Pembangunan Daerah Bali Cabang Singaraja. E-Journal S-1 Akuntansi, Universitas Pendidikan Ganesha, Vol. 3 (1), pp: 1-12.

Partomo. S.T. dan Abdul Rahman S. (2002). Ekonomi Skala Kecil / Menengah \& Koperasi. PT. Ghalia Indonesia, Jakarta.

Peraturan Bank Indonesia No. 14/22/PBI/2012 tentang Pemberian Kredit atau Pembiayaan oleh Bank Umum dan Bantuan Teknis dalam rangka Pengembangan Usaha Mikro, Kecil, dan Menengah.

Ruwanti and Pandi Afandi. (2014). Persepsi Nasabah pada Aspek 5C untuk Menentukan Kelayakan Pemberian Kredit pada Nasabah PT. BPR Nusamba Ampel Cabang Salatiga. Jurnal STIE Semarang, Vol. 6 (1), pp: 59-74.

Suyatno, Thomas, dkk. (2007). Dasar-Dasar Perkreditan, Edisi Keempat. PT. Gramedia Pustaka Utama, Jakarta.

Tambunan, Tulus. (2002). Usaha Kecil dan Menengah di Indonesia: Beberapa Isu Penting. PT. Salemba Empat, Jakarta.

Undang-Undang No. 20 Tahun 2008 tentang Usaha Mikro, Kecil dan Menengah.

Undang-Undang No. 9 Tahun 1995 tentang Usaha Kecil.

Undang-Undang No. 44 Tahun 1997 tentang Kemitraan.

Wibowo, Singgih, Murdinah, dan Nuri Yusro Fawyza. (2012). Pedoman Mengelola Perusahaan Kecil. PT. Penebar Swadaya, Jakarta.

Wismiarsi, Tri Shihab, Muchsin Saggaff Shihab, dan Adidarma Wijaya. (2008). Hambatan Ekspor UKM Indonesia: Hasil Studi pada Industri Mebel, Kerajinan, dan Biofarma. Buku Kompas, Jakarta. 